\title{
The mineral, proximate and phytochemical components of ten Nigerian medicinal plants used in the management of arthritis
}

\author{
Gbadamosi, I. T.* and Oloyede A. A. \\ Department of Botany, University of Ibadan, Ibadan, Nigeria. \\ Received 11 April, 2013; Accepted 16 May, 2014
}

\begin{abstract}
Ethnobotanical investigation revealed the use of ten medicinal plants in the management of arthritis in Ibadan, Nigeria. This study screened the plants for mineral, proximate and phytochemical components that could be responsible for their therapeutic value in arthritis. The powdered plant samples were analysed for nutritional constituents and phytochemical compounds using standard laboratory protocols. The use value of plant-parts was $50 \%$ leaves and $50 \%$ roots. Three out of the 10 plants had high calcium content: Oncoba spinosa $(180.0 \mathrm{mg} / 100 \mathrm{~g})$, Nymphaea lotus $(160.0 \mathrm{mg} / 100 \mathrm{~g})$ and Solenostemon monostachyus $(125.0 \mathrm{mg} / 100 \mathrm{~g})$. $N$. lotus had the highest iron content $(8.0 \mathrm{mg} / 100 \mathrm{~g})$. Phosphorus content was highest in 0 . spinosa $(150.0 \mathrm{mg} / 100 \mathrm{~g})$. Magnesium was highest in Phyllanthus amarus (14.0 mg/100 g). Crude fibre was highest in Solanum aethiopicum (15.90\%) and the least in 0 . spinosa (14.00\%). S. aethiopicum had the highest protein content $(18.50 \%)$ and 0 . spinosa the least (14.75\%). All the medicinal plants tested positive to alkaloids, carotenoids and flavonoids. The plants contained minerals and secondary metabolites that are implicated in arthritis viz. calcium, zinc, carotenoids and flavonoids. The presence of these compounds in the test plants might alleviate pains associated with arthritis. $O$. spinosa had high potential in the management of arthritis due to its high calcium and phosphorus components.
\end{abstract}

Key words: Arthritis, medicinal plants, mineral analysis, proximate analysis, Nigeria.

\section{INTRODUCTION}

Lecaniodiscus cupanioides Planch ex Benth., Carpolobia lutea G.Don, Microdesmis puberula Hook.f. ex Planch., Oncoba spinosa Forssk., Calliandra portoricensis (Jacq.) Benth., Phyllanthus amarus Schumach. \& Thonn., Solenostemon monostachyus (P.Beauv.) Briq., Tetracera alnifolia Willd., Solanum aethiopicum L. and Nymphaea lotus L. are used for the management of arthritis in Ibadan, Nigeria. Although the plants are of therapeutic importance in managing arthritis, they are used for other health problems in folk medicine. The aqueous root

*Corresponding a uthor. E-mail: gita4me2004@yahoo.com. 
extract of $L$. cupanioides is used as a galactogen and as a laxative (Adeyemi et al., 2005). C. lutea is used in folk medicine to facilitate delivery and treat male sexual disorders (Mitaine-Offer et al., 2002). M. puberula is used traditionally for the treat-ment of infectious diseases, genital problems, menstrual complaints, sterility, miscarriage and loss of virility. The roots of $O$. spinosa are used in the treatment of dysentery and bladder complaints (Burkill, 1994). C. portoricensis is mixed with ginger and water for use as an enema for lumbago pain and constipation, and when mixed with pepper; it is used for gonorrhoea (Burkill, 1985). The root has very strong anticandidal property (Gbadamosi, 2008). The leaves of S. monostachyus are eaten as a potherb; leaves are also used to treat dysmenorrhoea, haematuria, female sterility, rheumatism, foot infections and snakebites (Burkill, 1995). The roots of $T$. alnifolia are used for the treatment of venereal diseases, arthritis and rheumatism. The stem bark of the plant forms part of a recipe used as antianaemic (Gbadamosi et al., 2012). Medicinal applications of $S$. aethiopicum include the use of roots and fruits as a carminative and sedative, and to treat colic and high blood pressure. The leaf juice is used as a sedative to treat uterine complaints (Burkill, 2000). N. lotus finds application in the management of circulatory system disorders, digestive system disorders, infections and inflammation (Burkill, 1997).

Arthritis is the inflammation of one or more joints. Most forms of arthritis affect the joints, tendons, ligaments, muscles, and cartilage. Some types, in the advanced stages, can affect the body's organs. Although there is no cure for arthritis, pain relievers, certain natural substances including vitamins and minerals, exercise and other lifestyle remedies can help manage the disease. The symptoms of arthritis will depend on the cause and the type. If the cause of arthritis is an autoimmune condition, then the symptoms may occur suddenly and aggressively. Many people with autoimmune forms of arthritis will experience alternating periods of flare-ups and remission. If the cause of arthritis is related to aging, then the symptoms will occur gradually - sometimes over a period of years. No matter the type of arthritis, the symptoms will vary based on other factors, including overall health of the sufferer. Regardless of the type of arthritis, common symptoms include pain, swelling in the tissue and joints, stiffness, deformity and diminished flexibility. People with arthritis tend to experience an aching sensation that may improve or worsen as a result of factors that include weather, time of day, movement and physical activity (www.symptomfind.com).

There are more than one hundred identifiable types of arthritis. Some common types of arthritis are osteoarthritis, rheumatoid arthritis, gout, ankylosing spondylitis, psoriatic arthritis and juvenile arthritis. Osteoarthritis occurs when the joints break down from wear and tear as a result of old age or injury. Rheumatoid arthritis is an autoimmune disease that occurs when the immune system attacks its own cartilage and tendons between the joints. Gout is caused by excess uric acid in the blood; it is a sudden and severe attack that causes pain and swelling in the joints especially in the joint of the big toe. Ankylosing spondylitis causes swelling, pain, stiffness and other complications in the spine. Psoriatic arthritis is similar to rheumatoid arthritis and tends to affect the fingers. Juvenile arthritis affects children. Most children who have juvenile arthritis will develop symptoms of a sudden fever and swelling knuckles. Juvenile arthritis patients may also develop a rash. Many children who develop this form of rheumatoid arthritis will recover completely, while others face a lifelong chronic condition (www.symptomfind.com).

Some medicinal plants have been reported to be useful in the management of rheumatoid arthritis. Linum usitatissimum (flaxseed) oil can be an effective part of a rheumatoid arthritis treatment regimen. It is rich in Omega-3 fatty acids like alpha-lipoic acid, which have anti-inflammatory properties. Also useful is Tripterygium wilfordii (thunder god vine) which has unique immune suppressant and anti-inflammatory properties. Curcuma longa (turmeric) is a potent herbal remedy for rheumatoid arthritis symptoms. It contains curcumin, which gives it both its characteristic yellow color and anti-inflammatory properties (Neidzooicha, 2013). Other plants with antiinflammatory properties are Ageratum conyzoides, Artemisia copa, Bauhinia tarapotensis, Croton pullei and Maytenus ilicifolia (Lima et al., 2011). There is a lot of information in literature on plants with anti-inflammatory properties worldwide (Rathore et al., 2007; Adams et al., 2009; Vikrant and Arya, 2011; Vishwabhan et al., 2011; Mahesh et al., 2011; Apu et al., 2012). Medicinal plants with analgesic properties also play significant role in alleviating pains commonly associated with arthritis. Many plant analgesics have been reported (Santos et al., 1994; Mathangi et al., 2012).

This study analysed ten medicinal plants for their nutritional and phytochemical components with the aim of ascertaining their justification for ethnomedicinal uses in the management of arthritis. Furthermore, this study presents the test plants for future pharmacological and toxicological studies in related research fields.

\section{MATERIALS AND METHODS}

\section{Ethnobotanical study}

Twenty herb-sellers were interviewed on the traditional method of management of arthritis (Sofowora, 1993). They were interviewed in Yoruba language at a local herbal market (Bode) in Ibadan. The study revealed the use of $L$. cupanioides (roots), C. lutea (roots), $M$. puberula (roots), $O$. spinosa (roots), C. portoricensis (roots), $P$. amarus (leaves), S. monostachyus (leaves), T. alnifolia (leaves), $S$. aethiopicum (leaves) and $N$. lotus (leaves) for the management of arthritis in Ibadan, Oyo state, Nigeria. 


\section{Collection and Identification of botanicals}

The test plants were identified at species level in the University of lbadan Herbarium (UIH). Fresh and healthy plant parts of the test plants were either bought from the herbal market (Bode) or collected from University of Ibadan campus.

\section{Preparation of powdered plant materials for experiment}

The test plants were washed, cut into small pieces and air dried at room temperature $\left(27\right.$ to $\left.30^{\circ} \mathrm{C}\right)$ for two weeks until completely dried. The dry plant materials were ground into powder and stored in airtight glass bottles at room temperature prior to experiments.

\section{Mineral analysis of powdered plant samples}

The mineral analysis of samples was done using standard protocol (Walsh, 1971). After wet digestion, samples were analysed for Calcium (Ca), Iron (Fe), Manganese (Mn), Magnesium ( $\mathrm{Mg}$ ), and Zinc (Zn) using atomic absorption spectrophotometer (FC 210/211 VGP Bausch scientific AAS). Phosphorus $(P)$ was determined using Vanadomolybdate (Yellow method). Percentage transmittance was determined at $400 \mathrm{~nm}$ using Spectronic 20 (Bausch and Lomb) Colorimeter.

\section{Proximate analysis of powdered plant samples}

The proximate analysis of powdered plant materials was carried out using the AOAC methods (2005) in the Laboratory of the Department of Animal Science, Faculty of Agriculture and Forestry, University of Ibadan. The plant samples were analysed for proximate compositions: moisture content, crude protein, crude fat, ash, crude fibre and carbohydrate.

\section{Phytochemical screening of powdered plant samples}

Phytochemical screening of samples was done using the methods of Sofowora (1993) and Evans (2002) as follows.

\section{Alkaloids}

The powdered plant sample $(500 \mathrm{mg}$ ) was weighed and extracted with $10 \mathrm{ml}$ of $2 \%$ hydrochloric acid $(\mathrm{HCl})$. The $\mathrm{HCl}$ extract was then filtered with Whatman filter paper (No.1) so as to have a clear solution and also to prevent false results. The filtrate of about $2.5 \mathrm{ml}$ was treated with few drops of Dragendorff's reagent. A precipitate indicated the presence of alkaloids.

\section{Anthraquinones}

The powdered plant sample $(500 \mathrm{mg}$ ) was shaken with $10 \mathrm{ml}$ of benzene. The solution was filtered and $5 \mathrm{ml}$ of $10 \%$ ammonium hydroxide $\left(\mathrm{NH}_{4} \mathrm{OH}\right)$ solution was added to the filtrate. A violet colour was observed in the lower phase. It indicated presence of anthraquinones.

\section{Carotenoids}

The extract $(10 \mathrm{ml})$ was added to a test tube and evaporated to dryness on a water bath. 2 to 3 drops of saturated antimony (III) chloride $\left(\mathrm{SbCl}_{3}\right)$ in Chloroform $\left(\mathrm{CHCl}_{3}\right)$ was added to the residue. $\mathrm{A}$ blue-green colour eventually changing to red indicates the presence of carotenoids.

\section{Flavonoids}

A few drops of concentrated hydrochloric acid $(\mathrm{HCl})$ were added to a small amount of an extract $(0.5 \mathrm{~g})$ of the plant material. Immediate development of a red colour was taken as an indication of the presence of flavonoids.

\section{Saponins}

The sample $(200 \mathrm{mg}$ ) was shaken with $5 \mathrm{ml}$ of distilled water and then heated to boil. Persistent frothing showed the presence of saponins.

\section{Steroids}

The extract $(0.5 \mathrm{~g})$ was dissolved in $2 \mathrm{ml}$ of chloroform. Sulphuric acid was carefully added to form a lower layer. A reddish-brown colour at the interphase indicated the deoxysugar characteristic of cardenolides. A violet ring formed just above the layer and gradually spread throughout the layer (sulphuric acid) indicated presence of steroids.

\section{Tannins}

The sample $(500 \mathrm{mg}$ ) was mixed with $10 \mathrm{ml}$ of distilled water and heated on a water bath. The mixture was filtered and ferric chloride $\left(\mathrm{FeCl}_{3}\right)$ was added to the filtrate. Appearance of blue black colouration showed the presence of tannins.

\section{Statistical analysis of data}

All data were statistically analysed using one-way analysis of variance (ANOVA) and expressed as mean \pm SD. The Duncan multiple range test (DMRT) was used to test means for significance $(P<0.05)$.

\section{RESULTS}

Table 1 shows the profile of the medicinal plants used in this study. Herbs $(40 \%)$ are mostly used, followed by shrubs $(30 \%)$ and trees $(30 \%)$. The plants contained minerals in varied quantities (Table 2). The ten plants are rich in proteins and fibres (Table 3). Most of the medicinal plants tested positive to alkaloids, anthraquinones, carotenoids, flavonoids, saponins, steroids and tannins (Table $4)$.

\section{DISCUSSION}

The ten plants belong to 10 different families (Table 1). The use value of plant-parts was $50 \%$ leaves and $50 \%$ roots commonly used for the management of arthritis. Some traditional recipes used for the management of 
Table 1. Profile of ten medicinal plants used in the management of arthritis.

\begin{tabular}{lllll}
\hline Plant species & Family & Local names & Habit & Part used \\
\hline Lecaniodiscus cupanioides & Sapindaceae & Aaka & Tree & Roots \\
Carpolobia lutea & Polygalaceae & Osunsun & Shrub & Roots \\
Microdesmis puberula & Pandaceae & Apata & Shrub & Roots \\
Oncoba spinosa & Flacourtiaceae & Gbonsere & Tree & Roots \\
Calliandra portoricensis & Fabaceae & Tude & Shrub & Roots \\
Phyllanthus amarus & Euphorbiaceae & Eyin olobe & Herb & Leaves \\
Solenostemon monostachyus & Lamiaceae & Olojogbodu & Herb & Leaves \\
Tetracera alnifonia & Dilleniaceae & Opon & Tree & Leaves \\
Solanum aethiopicum & Solanaceae & Igbagba/Osun & Herb & Leaves \\
Nymphaea lotus & Nymphaceae & Osibata & Herb & Leaves \\
\hline
\end{tabular}

Table 2. Mineral constituents of ten medicinal plants used in the management of arthritis.

\begin{tabular}{lcccccc}
\hline Plant species & $\begin{array}{c}\text { Phosphorous } \\
(\mathbf{m g} / \mathbf{1 0 0} \mathbf{~})\end{array}$ & $\begin{array}{c}\text { Calcium } \\
(\mathbf{m g} / \mathbf{1 0 0} \mathbf{~})\end{array}$ & $\begin{array}{c}\text { Iron } \\
(\mathbf{m g} / \mathbf{1 0 0} \mathbf{~ g})\end{array}$ & $\begin{array}{c}\text { Manganese } \\
(\mathbf{m g} / \mathbf{1 0 0} \mathbf{~ g})\end{array}$ & $\begin{array}{c}\text { Magnesium } \\
(\mathbf{m g} / \mathbf{1 0 0} \mathbf{~ g})\end{array}$ & $\begin{array}{c}\text { Zinc } \\
(\mathbf{m g} / \mathbf{1 0 0} \mathbf{~ g})\end{array}$ \\
\hline Lecaniodiscus cupanioides & $* 125.00^{\mathrm{b}} \pm 4.24$ & $85.00^{\mathrm{a}} \pm 1.41$ & $7.50^{\mathrm{b}} \pm 0.14$ & $0.00^{\mathrm{a}} \pm 0.00$ & $2.50^{\mathrm{bdec}} \pm 0.14$ & $0.10^{\mathrm{a}} \pm 0.06$ \\
Carpolobia lutea & $60.00^{\mathrm{a}} \pm 2.83$ & $75.00^{\mathrm{f}} \pm 1.41$ & $6.35^{\mathrm{c}} \pm 0.21$ & $0.02^{\mathrm{a}} \pm 0.01$ & $4.50^{\mathrm{a}} \pm 0.14$ & $0.05^{\mathrm{a}} \pm 0.01$ \\
Microdesmis puberula & $70.00^{\mathrm{f}} \pm 1.14$ & $50.00 \pm 1.41$ & $2.45^{\mathrm{g}} \pm 0.07$ & $0.02^{\mathrm{a}} \pm 0.01$ & $1.50^{\mathrm{ed}} \pm 0.14$ & $0.02^{\mathrm{a}} \pm 0.01$ \\
Oncoba spinosa & $150.00^{\mathrm{a}} \pm 1.141$ & $180.00^{\mathrm{a}} \pm 1.41$ & $5.50^{\mathrm{d}} \pm 0.14$ & $0.02^{\mathrm{a}} \pm 0.01$ & $3.00^{\mathrm{bdac}} \pm 1.41$ & $0.05^{\mathrm{a}} \pm 0.06$ \\
Calliandra portoricensis & $85.00^{\mathrm{a}} \pm 1.41$ & $60.00^{\mathrm{h}} \pm 1.41$ & $6.25^{\mathrm{c}} \pm 0.07$ & $0.01^{\mathrm{a}} \pm 0.01$ & $4.00^{\mathrm{ba}} \pm 1.41$ & $0.10^{\mathrm{a}} \pm 0.01$ \\
Phyllanthus amarus & $45.00^{\mathrm{h}} \pm 1.41$ & $70.00^{\mathrm{g}} \pm 1.41$ & $6.00^{\mathrm{e}} \pm 0.14$ & $0.02^{\mathrm{a}} \pm 0.0$ & $14.00^{\mathrm{ba}} \pm 1.41$ & $0.10^{\mathrm{a}} \pm 0.01$ \\
Solenostemon monostachyus & $90.00^{\mathrm{d}} \pm 1.41$ & $125.00^{\mathrm{c}} \pm 1.41$ & $4.50^{\mathrm{e}} \pm 0.14$ & $0.01^{\mathrm{a}} \pm 0.01$ & $3.00^{\mathrm{bdac}} \pm 1.41$ & $0.02^{\mathrm{a}} \pm 0.01$ \\
Tetracera alnifonia & $55.00^{\mathrm{g}} \pm 1.41$ & $40.00^{\mathrm{j}} \pm 1.41$ & $3.55^{\mathrm{f}} \pm 0.07$ & $0.02^{\mathrm{a}} \pm 0.01$ & $1.00^{\mathrm{a}} \pm 0.57$ & $0.05^{\mathrm{a}} \pm 0.01$ \\
Solanum aethiopicum & $60.00^{\mathrm{g}} \pm 2.83$ & $95.00^{\mathrm{d}} \pm 1.41$ & $6.00^{\mathrm{c}} \pm 0.14$ & $0.08^{\mathrm{a}} \pm 0.10$ & $3.50^{\mathrm{bac}} \pm 0.14$ & $0.05^{\mathrm{a}} \pm 0.01$ \\
Nymphaea lotus & $120.00^{\mathrm{c}} \pm 1.41$ & $160.00^{\mathrm{b}} \pm 1.41$ & $8.00^{\mathrm{a}} \pm 0.28$ & $0.01^{\mathrm{a}} \pm 0.01$ & $2.00^{\mathrm{dec}} \pm 0.28$ & $0.01^{\mathrm{a}} \pm 0.06$ \\
\hline
\end{tabular}

*Value $=$ mean $\pm S D$

arthritis are: (i) the leaves of $P$. amarus and $S$. monostarchyus (1:1) are squeezed together in water and the extract $(150 \mathrm{ml})$ is taken daily after food. (ii) The root of $L$. cupanioides is dried and powdered; a teaspoonful of the powder is taken in hot water or pap daily after food. (iii) The root of $C$. portoricensis is dried and powdered; a teaspoonful of the powder is taken in hot water or pap daily after food.

Phosphorus content was highest in O. spinosa (150.0 $\mathrm{mg} / 100 \mathrm{~g}$ ) (Table 2), followed by L. cupanoides (120.0 $\mathrm{mg} / 100 \mathrm{~g})$. L. cupanioides $(125.0 \mathrm{mg} / 100 \mathrm{~g})$ and the least was for $P$. amarus $(45.0 \mathrm{mg} / 100 \mathrm{~g})$. Three out of the 10 plants had high calcium content: $O$. spinosa (180.0 $\mathrm{mg} / 100 \mathrm{~g}), \quad N$. lotus $(160.0 \mathrm{mg} / 100 \mathrm{~g})$ and $S$. monostachyus $(125.0 \mathrm{mg} / 100 \mathrm{~g})$. Calcium builds and maintains strong bones and teeth. A daily intake of 1,500 $\mathrm{mg}$ is recommended for people with inflammatory conditions. Calcium needs to be combined with phosphorus and vitamin $D$ to be more effective. People with rheumatoid arthritis who took $1,000 \mathrm{mg}$ of calcium along with $500 \mathrm{IUs}$ of vitamin D reversed steroid-induced bone loss and gained bone mass as well (Holt, 2011). $N$. lotus had the highest iron content $(8.0 \mathrm{mg} / 100 \mathrm{~g})$, followed by $L$. cupanioides $(7.50 \mathrm{mg} / 100 \mathrm{~g})$ and $M$. puberula the least at $2.45 \mathrm{mg} / 100 \mathrm{~g}$. There is an earlier report on high iron content $(7.78 \mathrm{mg} / \mathrm{g}$ ) in $\mathrm{N}$. lotus (Okayi and Abe, 2000). Magnesium was highest in $P$. amarus $(14.0 \mathrm{mg} / 100 \mathrm{~g})$, followed by C. lutea $(4.5 \mathrm{mg} / 100 \mathrm{~g})$ and the least was for $T$. alnifolia $(1.0 \mathrm{mg} / 100 \mathrm{~g})$. The antioxidant activity and ion profiles of $C$. lutea have been reported (Nwidu et al., 2012). The highest zinc value (0.1 $\mathrm{mg} / 100 \mathrm{~g}$ ) was observed for $L$. cupanioides, $C$. portoricensis and $P$. amarus. Zinc is often deficient in people with arthritis and a daily intake of $50 \mathrm{mg}$ is recommended for arthritis sufferers (Holt, 2011). The findings of the present study on mineral components of the test plants conform to the reports of previous authors (Nwidu et al., 2012; Afolabi et al., 2012). Overall, O. spinosa is a valuable plant in the management of arthritis due to its high phosphorus and calcium content.

Moisture content was highest in $S$. aethiopicum $(9.50 \%)$ and the least was for O. spinosa $(8.45 \%)$ (Table 3$)$. 
Table 3. Proximate components of ten medicinal plants used in the management of arthritis

\begin{tabular}{lcccccc}
\hline Plant species & $\begin{array}{c}\text { \% Moisture } \\
\text { Content }\end{array}$ & \% Protein & \% Crude fat & \%Ash & \% Crude fibre & \% Carbohydrate \\
\hline Lecaniodiscus cupanioides & ${ }^{*} 9.25^{\mathrm{bac}} \pm 0.07$ & $17.55^{\mathrm{b}} \pm 0.07$ & $2.20^{\mathrm{a}} \pm 0.14$ & $9.80^{\mathrm{bc}} \pm 0.28$ & $15.50^{\mathrm{ba}} \pm 0.14$ & $45.70^{\mathrm{h}} \pm 0.14$ \\
Carpolobia lutea & $8.90^{\mathrm{edc}} \pm 0.14$ & $15.25^{\mathrm{e}} \pm 0.21$ & $1.60^{\mathrm{bc}} \pm 0.28$ & $7.95^{\mathrm{f}} \pm 0.07$ & $14.25^{\mathrm{dc}} \pm 0.07$ & $52.10^{\mathrm{a}} \pm 0.14$ \\
Microdesmis puberula & $8.75^{\mathrm{ed}} \pm 0.07$ & $16.85^{\mathrm{c}} \pm 1.41$ & $1.40^{\mathrm{c}} \pm 0.14$ & $8.65^{\mathrm{e}} \pm 0.07$ & $15.50^{\mathrm{cd}} \pm 0.42$ & $48.85^{\mathrm{e}} \pm 0.21$ \\
Oncoba spinosa & $8.45^{\mathrm{ba}} \pm 0.07$ & $14.75^{\mathrm{f}} \pm 0.07$ & $2.05^{\mathrm{a}} \pm 0.07$ & $8.50^{\mathrm{e}} \pm 0.14$ & $14.00^{\mathrm{d}} \pm 0.14$ & $51.25^{\mathrm{b}} \pm 0.21$ \\
Calliandra portoricensis & $8.50^{\mathrm{e}} \pm 0.42$ & $15.90^{\mathrm{d}} \pm 1.41$ & $1.40^{\mathrm{c}} \pm 0.14$ & $9.55^{\mathrm{c}} \pm 0.07$ & $15.05^{\mathrm{b}} \pm 0.07$ & $49.60^{\mathrm{d}} \pm 0.14$ \\
Phyllanthus amarus & $8.70^{\mathrm{ed}} \pm 0.14$ & $16.70^{\mathrm{c}} \pm 0.28$ & $1.85^{\mathrm{ba}} \pm 0.28$ & $10.02^{\mathrm{a}} \pm 0.14$ & $14.60^{\mathrm{c}} \pm 0.28$ & $48.05^{\mathrm{f}} \pm 0.07$ \\
Solenostemon monostachyus & $8.95^{\mathrm{dc}} \pm 0.07$ & $18.50 \pm 0.28$ & $2.05^{\mathrm{a}} \pm 0.07$ & $9.85^{\mathrm{bc} \pm 0.07}$ & $13.85^{\mathrm{d}} \pm 0.07$ & $46.80^{\mathrm{g}} \pm 0.42$ \\
Tetracera alnifonia & $9.05^{\mathrm{bcc}} \pm 0.21$ & $15.85^{\mathrm{d}} \pm 0.07$ & $1.90^{\mathrm{ba}} \pm 0.14$ & $8.60^{\mathrm{e}} \pm 0.14$ & $14.05^{\mathrm{d}} \pm 0.21$ & $50.55^{\mathrm{c}} \pm 0.07$ \\
Solanum aethiopicum & $9.50^{\mathrm{a}} \pm 0.14$ & $17.90^{\mathrm{b}} \pm 0.14$ & $1.85^{\mathrm{ba}} \pm 0.07$ & $9.95^{\mathrm{ba}} \pm 0.21$ & $15.90^{\mathrm{a}} \pm 0.14$ & $44.85 \pm 0.07$ \\
Nymphaea lotus & $8.70^{\mathrm{ed}} \pm 0.14$ & $15.60^{\mathrm{ed}} \pm 0.28$ & $1.60^{\mathrm{bc}} \pm 0.28$ & $9.20 \pm 0.14$ & $15.40^{\mathrm{b}} \pm 0.00$ & $49.45 \pm 0.07$ \\
\hline
\end{tabular}

*Value $=$ mean \pm SD.

Table 4. Phytochemical quality of ten medicinal plants used in the management of arthritis.

\begin{tabular}{|c|c|c|c|c|c|c|c|}
\hline Plant species & Alkaloids & Anthraquinones & Carotenoids & Flavonoids & Saponins & Steroids & Tannins \\
\hline Lecaniodiscus cupanioides & + & + & + & + & + & + & \pm \\
\hline Carpolobia lutea & + & + & + & \pm & + & + & \pm \\
\hline Microdesmis puberula & + & + & + & + & + & + & + \\
\hline Calliandra portoricensis & + & + & + & \pm & + & + & + \\
\hline Phyllanthus amarus & + & + & + & + & + & + & + \\
\hline Solanum aethiopicum & + & + & + & + & + & + & + \\
\hline Nymphaea lotus & + & + & + & + & + & + & + \\
\hline
\end{tabular}

+ means presence; \pm means inconclusive.

S. aethiopicum had the highest protein content $(18.50 \%)$ and $O$. spinosa the least $(14.75 \%)$. The protein content of $S$. aethiopicum $(2.24 \pm 0.03$ $\mathrm{g} / 100 \mathrm{~g}$ protein) (17.90\%) observed in this study is higher than the value reported for its fruit (Chinedu et al., 2011). The ash content for $P$. amarus $(10.02 \%)$ was the highest and the least was recorded for $C$. lutea (7.95\%). Crude fibre was highest in S. aethiopicum (15.90\%) and the least in O. spinosa $(14.00 \%)$. The carbohydrate content of C. lutea $(52.10 \%)$ was the highest and $S$. aethiopicum $(44.85 \%)$ was the least. Generally, S. 
aethiopicum was highest in nutritional constituents (moisture, crude protein and crude fibre), a result that agrees with the findings of Chinedu et al. (2011).

The phytochemical components could be responsible for the analgesic, antioxidant and anti-inflammatory properties of the test plants and their effectiveness in the management of arthritis. The antioxidant properties of $P$. amarus (Joseph and Raj, 2011), S. aethiopicum (Okoko and Ere, 2012) and C. portoricensis (Moharram et al., 2006) have been reported. C. lutea (Jackson et al., 2011), C. portoricensis (Agunu et al., 2005) and $M$. puberula (Okany et al., 2012) have analgesic properties.

\section{Conclusion}

The test plants contained significant mineral, proximate and phytochemical components. The antioxidant, analgesic and anti-inflammatory properties of some of the plants have been reported, and these therapeutic properties are significantly relevant in the management of arthritis. The nutritional components of the test plant might complement the phytochemicals in alleviating pain and reducing inflammation in arthritis

\section{REFERENCES}

Adams M, Berset C, Kessler M, Hamburger M (2009). Medicinal herbs for the treatment of rheumatic disorders-A survey of European herbals from the $16^{\text {th }}$ and $17^{\text {th }}$ century. J. Ethnopharmacol. 121:343359.

Adeyemi OO, Yemitan OK, Adeogun OO (2005). Analgesic activity of the aqueous root extract of Lecaniodiscus cupanioides. West Afr. J. Pharmacol. Drug Res. 20(1,2):10-14.

Afolabi IS, Akpokene ON, Fashola DV, Famakin TC (2012). Comparative evaluation of the nutritional benefits of some underutilized plants leaves. J. Nat. Prod. Plant Resour. 2(2):261-266.

Agunu A, Abdurahman EM, Shok M, Sadiq AY (2005). Analgesic activity of the roots and leaves of Calliandra portoricensis. Fitoterapia $76: 442-445$

AOAC (2005). Official Methods of Analysis. 18th Edition. Association of Official Analytical Chemists, Washington, DC., USA.

Apu AS, Bhuyan SH, Prova SS, Muhit MA (2012). Anti-inflammatory activity of medicinal plants native to Bangladesh: A review. J. Appl. Pharm. Sci. 2 (2):7-10.

Burkill HM (1985). The useful plants of West Tropical Africa. Royal Botanic Gardens Kew, 2nd edition, 2:413-414.

Burkill HM (1994). The useful plants of West Tropical Africa. Royal Botanic Gardens Kew, 2nd edition, 2:160-162.

Burkill HM (1995). The useful plants of West Tropical Africa. Royal Botanic Gardens Kew, 2nd edition, 3:34-35.

Burkill HM (1997). The useful plants of West Tropical Africa. Royal Botanic Gardens Kew, 2nd edition, 4:264-267.

Burkill HM (2000). The useful plants of West Tropical Africa. Royal Botanic Gardens Kew, 2nd edition, 5:120-121.

Chinedu SW, Olasumbo AC, Eboji OK, Emiloju OC, Arinola OK, Dania DI (2011). Proximate and Phytochemical Analyses of Solanum aethiopicum L. and Solanum macrocarpon L. Fruits. Res. J. Chem. Sci. 1(3):63-71.

Evans WC (2002). Trease and Evans Pharmacognosy, 15th Edition. London: Bailliere Tindall, p. 585.
Gbadamosi IT (2008). Ethnobotany and micro-propagation of selected medicinal plants with in vitro anti-candidal activity in Ibadan, southwestern Nigeria. Ph.D dissertation, University of Ibadan, Nigeria.

Gbadamosi IT, Moody JO, Yekini AO (2012). Nutritional composition of ten ethnobotanicals used for treatment anaemia in southwestern Nigeria. Eur. J. Med. Plants 2(2):140-150.

Holt B (2011). Vitamins and minerals for arthritis. Available at: www.livestrong.com/article/467878-vitamins-minerals-for-arthritis/. Retrieved $26^{\text {th }}$ March, 2013.

Jackson C, Mbagwu H, Jackson I, Ekpe G, Etienam F (2011). Analgesic activities of ethanolic extract of the root of Carpolobia lutea. Afr. J. Pharm. Pharmacol. 5(3):367-370.

Joseph B, Raj SJ (2011). An overview: Pharmacognostic properties of Phyllantus amarus Linn. Int. J. Pharmacol. 7(1):40-45.

Lima GRM, Montenegro CA, Almeida CLF, Athayde-Filho PF, BarbosaFilho JM, Batista LM (2011). Database Survey of Anti-Inflammatory Plants in South America: A Review. Int. J. Mol. Sci. 12:2692-2749.

Mahesh G, Ramkanth S, Mohammed Saleem TS (2011). Antiinflammatory drugs from medicinal plants a comprehensive review. Int. J. Rev. Life. Sci. 1(1):1-10.

Mathangi N, Elumalai E, Eswaraiah MC, Mamatha A, Swathi AS (2012). An updated analgesic review on medicinal plants - 2011. Int. J. Pharm. Res. Dev. 4(1):22-29.

Mitaine-Offer A, Miyamoto T, Khan IA, Delaude C, Dubois M (2002). Three new triterpenes saponins from two species of Carpolobia. J. Nat. Prod. 65:533-557.

Moharram FA, Marzouk MSA, Ibrahim MT, Marby TJ (2006). Antioxidant galloylated flavanol glycosides from Calliandra haematocephala, Nat. Prod. Res. 20:927-934.

Neidzooicha L (2013). Herbs to Get Rid of Rheumatoid Arthritis Pain in Knees. Available at: http://www.livestrong.com/article/303726-herbsto-get-rid-of-rheumatoid-arthritis-pain-in-knees /. Retrieved $26^{\text {th }}$ May, 2014.

Nwidu LL, Cilli EM, Vilegas W (2012). Amino acid, Antioxidant and Ion Profiles of Carpolobia lutea Leaf (Polygalaceae). Trop. J. Pharm. Res 11(5):807-813.

Okany CC, Ishola IO, Ashorobi RB (2012). Evaluation of analgesic and antistress potential of methanolic stem wood extract of Microdesmis puberula Hook.f. ex Planch (Pandaceae) in mice. Int. J. Appl. Res. Nat. Prod. 5(3):30-36.

Okayi RG, Abe OM (2000). Preliminary study of the aquatic macrophytes of selected fish ponds and reservoirs in Makurdi, Benue State, Nigeria. 165-168. Available at: www.aquaticcommons.org/3639/1/16P165.pdf Retrieved $26^{\text {th }}$ March, 2013.

Okoko T, Ere D (2012). Antioxidant activities of Solenostemon monostachyus leaf extract using in vitro methods. Sci. Res. Essays 7(6):621-626.

Rathore B, Mahdi AA, Paul BN, Saxena PN, Das SK (2007). Indian Herbal Medicines: Possible Potent Therapeutic Agents for Rheumatoid Arthritis. J. Clin. Biochem. Nutr. 41(1):12-17.

Santos AR, Filho VC, Niero R, Viana AM, Moreno FN, Campos MM, Yunes RA, Calixto JB (1994). Analgesic effects of callus culture extracts from selected species of Phyllanthus in mice. J. Pharm. Pharmacol. 46(9):755-759.

Sofowora A (1993). Medicinal Plants and Traditional Medicine in Africa, 2nd Edition. Ibadan, Nigeria: Spectrum Books Ltd. P 289.

Vikrant A, Arya ML (2011). A Review on anti-Inflammatory plant barks. Int. J. Pharm. Tech. Res. 3:899-908.

Vishwabhan S, Harsh P, Vishal S, Kailash S (2011). Some traditionally used anti-arthritic herbs a review. Int. Res. J. Pharm. 2(11):43-45.

Walsh LM (1971). Instrumental methods for analysis of soils and plant tissue. Madison. Wis. USA: Soil Sci. Society Am. Inc., p. 222.

Symptomfind (2014). Arthritis. http://www.symptomfind.com/diseases-conditions/arthritis/. Retrieved $26^{\text {th }}$ March, 2013. 